\title{
Editorial: Biogeochemistry and Genomics of Silicification and Silicifiers
}

\author{
Brivaëla Moriceau ${ }^{1 *}$, Marion Gehlen ${ }^{1}$, Paul Tréguer $^{1}$, Stephen Baines ${ }^{2}$, Jacques Livage ${ }^{3}$ \\ and Luc André 4 \\ ${ }^{1}$ CNRS, IRD, Ifremer, LEMAR, Univ. Brest, Plouzane, France, ${ }^{2}$ Department of Ecology and Evolution, Stony Brook University, \\ Stony Brook, NY, United States, ${ }^{3}$ Chimie de la Matière Condensée, CNRS-UMR 7574, UPMC, Paris, France, ${ }^{4}$ Royal \\ Museum for Central Africa, Tervuren, Belgium
}

Keywords: silicon cycle, biogenic silica, diatom, isotope, Bolidophycae, sponge (Porifera), nanostructured silica, anthropogenic pressure

\section{Editorial on the Research Topic}

\section{Biogeochemistry and Genomics of Silicification and Silicifiers}

Silicon ( $\mathrm{Si}$ ) is continuously created in the universe by the thermonuclear fusion of oxygen atoms, mainly in massive stars (Woosley et al., 1973). Although silicon and carbon have similar electron configurations, life on Earth is based on carbon and not on silicon. The high stability of Si-O bound under the oxidizing conditions of the Earth's atmosphere and seas means that solid mineral $\mathrm{SiO}_{2}$ is the end product of most chemical reactions involving Si. The discovery of the oldest putative

\section{OPEN ACCESS}

Edited and reviewed by: Eric 'Pieter Achterberg, GEOMAR Helmholtz Center for Ocean Research Kiel, Germany

*Correspondence:

Brivaëla Moriceau moriceau@univ-brest.fr

Specialty section:

This article was submitted to Marine Biogeochemistry, a section of the journal Frontiers in Marine Science

Received: 30 November 2018 Accepted: 01 February 2019

Published: 19 March 2019

Citation:

Moriceau B, Gehlen M, Tréguer P, Baines S, Livage $J$ and André L (2019)

Editorial: Biogeochemistry and

Genomics of Silicification and Silicifiers. Front. Mar. Sci. 6:57.

doi: 10.3389/fmars.2019.00057 evidence for life in $\mathrm{SiO}_{2}$-rich chert deposits, stimulated a debate about the role of silica $\left(\mathrm{SiO}_{2}\right)$ in the emergence of life (e.g., Derenne et al., 2008). Nowadays, silica is present in most lineages of living organisms, often conferring some defensive advantage (Hodson et al., 2005; Exley, 2015). The main biologically available form of $\mathrm{Si}$ is also the most common species of dissolved $\mathrm{Si}$ (DSi), silicic acid $\left(\mathrm{Si}(\mathrm{OH})_{4}\right)$. Silicic acid was present at very high concentrations in natural waters during Earth's early history, which promoted the formation of mineral silica that was then deposited on to the seafloor. Some organisms eventually evolved the ability to biosynthesize organized silica skeletons through a condensation reaction between a silanol group of silicic acids and the hydroxyl group of silaffins, silacidins, and silicateins which act as scaffolds (e.g., Kröger et al., 1999). In the marine realm, $240 \mathrm{Tmol}$ of silica are produced each year (Tréguer et al., 1995) as compared to $84 \mathrm{Tmol}$ of Si in the terrestrial realm (Conley and Carey, 2015). Si is required for the growth of diatoms and some sponges. It is also utilized by radiolarians, silicoflagellates, several species of choanoflagellates, and can accumulate in some picocyanobacteria (Baines et al., 2012).

Over the past 550 years, different silicifiers in the marine realm have successively dominated (Conley et al. this issue). Most recently, diatoms have dominated the Si cycle owing to their great abundance, fast growth rate and high affinity for silicic acid. Over this period, they have stripped the ocean of silicic acid, bringing concentrations down to an average of $73 \mu \mathrm{M}$ in the deep sea and $<10 \mu \mathrm{M}$ in surface waters, as indicated by the tendency for their frustules to become less silicified over geological time (i.e., lower Si/C, Si/N ratios) (Tréguer et al., 1995). Despite the reduced levels of available Si, diatoms are responsible for about 1/4th of the primary production of planet Earth and half of the carbon flux to the deep ocean via the "biological pump" (review in Tréguer et al., 2018). Since 2004, the genomes of several diatom species have been deciphered. Differences to those of terrestrial plants reflect the complex evolution/adaptation of diatoms 
in response to the drastic variations of the ocean composition since the early Jurassic period (Armbrust et al., 2004). Development of genomic tools in the last few years, may strongly augment traditional biogeochemistry and biological approaches, and enhance our understanding of the Si cycle, silicification processes and the role of silicifiers in ecosystems.

For this reason, the first SILICAMICS conference was held near Brest (France) in September 2015. This conference, endorsed by European institutions, included researchers from multiple disciplines (including chemistry, biogeochemistry, biochemistry, physiology, genomics) and reviewed extant knowledge on silicification and silicifiers, underlining the importance of working across disciplines, as well as considering all silicifiers and their respective roles in the ecosystem and the Si cycle. The following questions were addressed:

1-What processes drive the variations of silicic acid and of its isotopes in the oceans through geologic time and in the present time?

Conley et al. combine genomic and geological data to suggest that biological processes have influenced oceanic silicic acid concentrations (DSi) ever since oxygenic photosynthesis first evolved. They show that a spectacular decrease in DSi in the global ocean was initiated first by bacterial Si related metabolism, followed by the evolution of different eukaryotic lineages capable of converting DSi into mineralized structures. Sutton et al. discuss the geochemical tools that are available for studying the Si cycle and highlight our present understanding of the marine, freshwater and terrestrial systems. They discuss challenges associated with the development of environmental proxies for the global Si cycle, and how each system within the global Si cycle might change over time. Meyerink et al. show how iron availability influences silicon isotope fractionation in two typical Southern diatoms. They describe how variations in the Si isotope enrichment factor can be explained by the adaptations of diatoms to the nutrient status of their environments.

2-What explains the success of silicifiers in the living world?

Hendry et al. examine fossils, sediments, and isotopic geochemistry to show the emergence and expansion of silica biomineralization in the ocean through geological time. Taking metagenomics data into account, they also discuss the competition between silicifiers and non-silicifiers as it has influenced evolutionary trajectories in the past, and how it affects the biogeochemical cycles of Si, C, and other nutrients in the present day. Among silicifiers, diatoms are one of the most efficient competitors, which allows them to build their silica frustules in only a few hours under unfavorable temperature and silicic acid conditions. Because the properties of biogenic silica have important technological applications, this unique capacity of diatoms has been scrutinized by the scientific community over the past 20 years. Hildebrand et al. recall that over this period, approaches used to characterize the molecular components involved in cell wall silicification have evolved, revealing that the diatom cell wall formation is highly dynamic. Mcheik et al. describe optical properties of nanostructured silica structures from marine organisms, and highlight interesting optical properties, such as light waveguiding, diffraction, focusing, and photoluminescence.
3-Which organisms play a major role in the control of the silicon cycle?

Kuwata et al. summarize the current information on taxonomy, phylogeny, ecology, and physiology obtained by recent studies using a range of approaches including metabarcoding of Bolidophycae, a sister picoplanktonic group of diatoms that contain species with cells surrounded by silica plates. Toullec and Moriceau show for the first time that transparent exopolymer particles (TEP) selectively increase biogenic silica dissolution from fossil diatoms compared to fresh diatoms. In line with results by Akagi (2013) they suggest that diatom excretion of TEP may accelerate the dissolution of refractory silica and provide an alternative source of DSi when limitations arise. Alvarez et al. extracted data from over 320,000 records of Porifera from the Global Biodiversity Information Facility (GBIF) to describe the overall distribution of sponge orders and families along DSi gradients and depth. They conclude that the use of sponge taxa assemblages as a proxy for DSi concentration or depth must be treated with caution as these animals are adapted to a great range of DSi conditions, as well as other unspecified variables that are also related to depth.

4-Silicifiers in a changing world

Diatoms are important drivers of the biological carbon pump, but their efficiency may be modulated by interactions with other organisms. In the mesocosm study described in Moriceau et al. an increase of copepod abundance boosts phytoplankton production through trophic cascade, but reduces the sinking flux of particulate organic carbon when diatoms dominate the phytoplankton community. Ragueneau et al.'s article, using a long-term research effort devoted to study the Si cycle of the bay of Brest, illustrates how human activity may impact and be affected by the competition between silicifiers and non-silicifying phytoplankton. They describe how the succession between diatom and toxic algal bloom may be controlled by invasive benthic organisms and diversity. Building on the strength of an interdisciplinary approach linking natural and social sciences, they propose a method for the improved use of the ecosystem while ensuring its sustainability.

\section{AUTHOR CONTRIBUTIONS}

$\mathrm{BM}$ and PT wrote the manuscript. MG, SB, JL, and LA corrected the manuscript.

\section{ACKNOWLEDGMENTS}

This research topic results from a collaborative effort initiated during the first international conference SILICAMICS, held in the Aber Wrac'h near Brest (France). This conference, that had the ambitious objective to better understand silicification processes and the role of silicifiers in the marine ecosystems, has been supported by Labex-Mer, EuroMarine, the University of Western Brittany, and Local Authorities from the région Bretagne. 


\section{REFERENCES}

Akagi, T. (2013). Rare earth element (REE)-silicic acid complexes in seawater to explain the incorporation of REEs in opal and the "leftover" REEs in surface water: new interpretation of dissolved REE distribution profiles. Geochim. Cosmochim. Acta 113, 174-192. doi: 10.1016/j.gca.2013.03.014

Armbrust, E. V., Berges, J. A., Bowler, C., Green, B. R., Martinez, D., Putnam, N. H., et al. (2004). The genome of the diatom Thalassiosira pseudonana: ecology, evolution, and metabolism. Science 306, 79-86. doi: 10.1126/science.1101156

Baines, S. B., Twining, B. S., Brzezinski, M. A., Krause, J. W., Vogt, S., Assael, D., et al. (2012). Significant silicon accumulation by marine picocyanobacteria. Nat. Geosci. 5, 886-891. doi: 10.1038/ngeo1641

Conley, D. J., and Carey, J. C. (2015). Biogeochemistry: Silica cycling over geologic time. Nat. Geosci. 8, 431. doi: 10.1038/ngeo2454

Derenne, S., Robert, F., Skrzypczak-Bonduelle, A., Gourier, D., Binet, L., and Rouzaud, J.-N. (2008). Molecular evidence for life in the 3.5 billion year old Warrawoona chert. Earth Planet. Sci. Lett. 272, 476-480. doi: 10.1016/j.epsl.2008.05.014

Exley, C. (2015). A possible mechanism of biological silicification in plants. Front. Plant Sci. 6:853. doi: 10.3389/fpls.2015.00853

Hodson, M. J., White, P. J., Mead, A., and Broadley, M. R. (2005). Phylogenetic variation in the silicon composition of plants. Ann. Bot. 96, 1027-1046. doi: $10.1093 / \mathrm{aob} / \mathrm{mci} 255$
Kröger, N., Deutzmann, R., and Sumper, M. (1999). Polycationic peptides from diatom biosilica that direct silica nanosphere formation. Science 286, 1129-1132.

Tréguer, P., Bowler, C., Moriceau, B., Dutkiewicz, S., Gehlen, M., Aumont, O., et al. (2018). Influence of diatom diversity on the ocean biological carbon pump. Nat. Geosci. 11, 27-37. doi: 10.1038/s41561-017-0028-x

Tréguer, P., Nelson, D. M., Bennekom, A. J. V., Demaster, D. J., Leynaert, A., and Quéguiner, B. (1995). The silica Balance in the World Ocean: a Reestimate. Science 268, 375-379.

Woosley, S. E., Arnett, W. D., and Clayton, D. D. (1973). The explosive burning of oxygen and silicon. Astrophys. J. Suppl. 26:231. doi: 10.1086/190282

Conflict of Interest Statement: The authors declare that the research was conducted in the absence of any commercial or financial relationships that could be construed as a potential conflict of interest.

Copyright (C) 2019 Moriceau, Gehlen, Tréguer, Baines, Livage and André. This is an open-access article distributed under the terms of the Creative Commons Attribution License (CC BY). The use, distribution or reproduction in other forums is permitted, provided the original author(s) and the copyright owner(s) are credited and that the original publication in this journal is cited, in accordance with accepted academic practice. No use, distribution or reproduction is permitted which does not comply with these terms. 